\title{
Uprawnienie posła pozbawionego wolności do otrzymywania diety i uposażenia poselskiego ${ }^{1}$
}

\footnotetext{
The right of a Deputy who is deprived of liberty to receive a parliamentary per diem allowance and a Deputy's salary (WAKiU-911/18): According to Article 5a of the Act on the Exercise of the Mandate of a Deputy or Senator at the time of deprivation of liberty the Deputy is not entitled to receive parliamentary per diem allowance or a salary. The period of preliminary custody is calculated from the date of detention. An expiry of the period of preliminary custody or repealing of the decision by a court restores to the Deputy a full enjoyment of rights and obligations, and thus enables to receive a parliamentary per diem allowance and a Deputy's salary.
}

Keywords: parliamentary per diem allowance, mandate, Deputy, deprivation of liberty, remuneration

Słowa kluczowe: dieta, mandat, poseł, pozbawienie wolności, wynagrodzenie

Ekspert ds. legislacji BAS; wojciech.sypniewski@sejm.gov.pl.

\section{Przedmiot opinii}

Przedmiotem opinii jest analiza sytuacji prawnej posła pozbawionego wolności. W szczególności chodzi o ocenę skutków zasady określonej w art. 5a ustawy z 9 maja 1996 r. o wykonywaniu mandatu posła i senatora (t.j. Dz.U. 2016, poz. 1510, ze zm.; dalej: ustawa lub u.w.m.p.s.) w odniesieniu do uprawnienia do otrzymywania diety i uposażenia poselskiego. W związku z tym zostanie przedstawiona odpowiedź na następujące pytania:

- „czy treść art. 5a ustawy o wykonywaniu mandatu posła i senatora upoważnia Kancelarię Sejmu do wstrzymania wypłaty diety i uposażenia poselskiego na czas pozbawienia wolności?,

- jeśli tak, to w jakim trybie powinno nastąpić wstrzymanie świadczeń i ewentualne wznowienie wypłaty uposażenia poselskiego i diety poselskiej?,

1 Opinia prawna w sprawie uprawnienia posła pozbawionego wolności do otrzymywania diety i uposażenia poselskiego sporządzona 26 kwietnia 2018 r. na zlecenie dyrektora Biura Obsługi Posłów; BAS-WAKiU 911/18. 
- czy konieczne jest podjęcie w tej sprawie uchwały Prezydium Sejmu, czy też wystarczające jest potwierdzenie faktu pozbawienia wolności np. poprzez zawiadomienie Marszałka Sejmu o tymczasowym aresztowaniu posła za pośrednictwem właściwego sądu?”.

\section{Założenia ustawodawcze (ratio legis) art. 5a ustawy a prawo do uposażenia i diety poselskiej ${ }^{2}$}

1. Zgodnie $\mathrm{z}$ art. 5a u.w.m.p.s.: Poseł lub senator $w$ czasie pozbawienia wolności nie wykonuje praw i obowiązków wynikajacych z niniejszej ustawy. Przepis ten ustanowiony został nowelą ustawy o wykonywaniu mandatu posła i senatora z 6 stycznia 2005 r. (Dz.U. nr 448, poz. 46; dalej: nowela ze stycznia 2005 r.) i służył rozstrzygnięciu wątpliwości, które powstały na tle konkretnego przypadku zatrzymania i tymczasowego aresztowania posła na Sejm $\mathrm{RP}^{3}$. Zaistniała sytuacja zaktualizowała dylematy związane z zakresem praw i obowiązków poselskich, które może wykonywać osoba pozbawiona wolności. Jakkolwiek w piśmiennictwie powszechnie wyrażany był pogląd, że w przypadku kolizji przepisów prawa karnego procesowego oraz wykonawczego i uprawnień wynikających z mandatu poselskiego pierwszeństwo należy przyznać unormowaniom prawnokarnym ${ }^{4}$, to jednak w praktyce delimitacja grupy praw, których wykonywanie w warunkach pozbawienia wolności jest niemożliwe, i tych, które mogłyby być skutecznie realizowane, rodziła istotne trudności. Nowelizacja ustawy ze stycznia 2005 r. zgodnie $\mathrm{z}$ intencją wyrażoną $\mathrm{w}$ projekcie służyć miała "przecięciu” tych wątpliwości. W ocenie wnioskodawcy projektu (grupa posłów): pozbawienie wolności z istoty

2 W opinii wykorzystuję ustalenia przedstawione w opinii prawnej w sprawie statusu posła pełniącego funkcję przewodniczącego komisji sejmowej na tle art. 5a ustawy o wykonywaniu mandatu posła i senatora, 17 kwietnia 2018 r., BAS-WAKiU 844/18, niepubl.

3 Poseł IV kadencji Sejmu A.P. po wyrażeniu przez Sejm zgody - uchwała Sejmu z 19 listopada 2004 r., MP nr 49 poz. 835 - został tymczasowo aresztowany przez organy ściągania.

4 J. Repel, Warunki wykonywania mandatu przez posła (senatora) tymczasowo aresztowanego lub skazanego na karę pozbawienia wolności, s. 29; K. Grajewski, Warunki wykonywania mandatu parlamentarnego przez posła (senatora) tymczasowo aresztowanego lub skazanego na karę pozbawienia wolności, s. 39; W. Odrowąż-Sypniewski, P. Radziewicz, Propozycje zmian do ustawy o wykonywaniu mandatu posła i senatora, dotyczące statusu posła pozbawionego wolności, s. 49; J. Mordwiłko, Możliwość ustawowego uregulowania ograniczenia sprawowania mandatu przedstawiciela pozbawionego wolności, w świetle Konstytucji RP, s. 53 - wszystkie wymienione opinie publikowane [w:] Status posła, cz. I, Wybór ekspertyz prawnych do art. 1-24 ustawy z 9 maja 1996 r. o wykonywaniu mandatu posła i senatora, red. J. Mordwiłko i in., Warszawa 2007. 
swej uniemożliwia wykonywanie mandatu w zakresie obejmującym uczestnictwo parlamentarzysty $w$ pracach Izby i jej organów - co stanowi jedno z podstawowych praw i obowiązków parlamentarzysty wchodzacych $w$ zakres wykonywania mandatu. Status prawny parlamentarzysty pozbawionego wolności, a tym samym potencjalnej możliwości wykonywania mandatu może okazać się zróżnicowany w zależności od przyczyny pozbawienia wolności. Szczegółowe rozróżnienie elementów wykonywania mandatu, które mogłyby być realizowane przez parlamentarzyste pozbawionego wolności, musiałoby być rozstrzygane indywidualnie w każdym przypadku, co zdaniem wnioskodawców uniemożliwia precyzyjna regulacje ustawowa, także ze względu na otwarty katalog form działalności mogacych wchodzić w zakres sprawowania mandatu (art. 6 ust. 2 u.w.m.p.s.). Mając na względzie powyższe, jak również konieczność dbałości o precyzyjne uregulowanie statusu parlamentarzysty pozbawionego wolności i zagwarantowanie przejrzystych zasad funkcjonowania parlamentu, wnioskodawcy uznali za najbardziej racjonalne i odpowiadajace potrzebom rozwiazanie polegajace na wprowadzeniu do systemu prawnego instytucji zawieszenia wykonywania mandatu. Oznaczać to będzie, że poseł pozbawiony wolności nie będzie mógł korzystać z uprawnień wynikających $z$ mandatu (dotyczy to także uprawnień o charakterze finansowo-socjalnym) [podkreślenie W.O.-S.], zachowując jednocześnie status parlamentarzysty. Zawieszenie wykonywania mandatu nie oznacza bowiem jego wygaśnięcia. W szczególności parlamentarzyście nadal przysługiwać będzie immunitet, co oznacza, że np.: postawienie nowych zarzutów możliwe będzie jedynie po spełnieniu warunków określonych $w$ art. 105 Konstytucji i odpowiednich przepisach ustawy o wykonywaniu mandatu posła i senatora (uzasadnienie projektu, druk nr 3576/IV kad.).

Ustanowienie zasady ogólnej ocenione zostało w doktrynie prawa konstytucyjnego bardzo krytycznie. Wskazywano, że przyjęta konstrukcja stoi w sprzeczności z art. 104 ust. 1 Konstytucji, ponieważ pozbawia deputowanego większości praw i obowiązków wiążących się z jego statusem. Samo posiadanie mandatu (w kontekście zawieszenia wynikających z niego praw) staje się pojęciem pustym, pozbawionym treści i w praktyce oznacza faktyczne pozbawianie mandatu przedstawicielskiego. Wskazywano również, że brak jest podstaw normatywnych do dyferencjacji „praw i obowiązków wynikających z ustawy” na te, które zostały skutecznie zawieszone oraz te (immunitet - rozdział 2 u.w.m.p.s.), które w dalszym ciągu mogą być wykonywane przez parlamentarzystę pozbawionego wolności. Krytyka przyjętego przez ustawodawcę rozwiązania nie była powiązana z generalną negacją potrzeby ustawowego określenia statusu pozbawionego wolności deputowanego. Wskazywano jednak, że nowe unormowanie powinno przybrać formę bardziej szczegółowego rozwiązania, które dopuszczałoby wykonywanie tych uprawnień i obowiązków, które nie kolidują ze statusem parlamentarzysty ${ }^{5}$.

5 K. Grajewski, Komentarz do art. 5a [w:] K. Grajewski, J. Stelina, P. Uziębło, Komentarz do ustawy o wykonywaniu mandatu posła i senatora, Warszawa 2014, s. 55-63. 
2. Niezależnie od oceny trafności krytyki wyrażanej przez przedstawicieli doktryny, omawiany przepis obowiązuje i cieszy się domniemaniem zgodności z Konstytucją RP. W konsekwencji organy stosujące prawo zobowiązane są do respektowania wyrażonej w nim zasady, co w szczególności zakłada obowiązek nadawania jej sensu, który w największym stopniu dawałby się pogodzić z ustawą zasadniczą. W dotychczasowej działalności analitycznej BAS (BSiE) wyrażany był pogląd, że: posłowi pozbawionemu wolności nie przysługuje prawo do uprawnień wynikajacych z rozdziału 5 ustawy poselsko-senatorskiej' ${ }^{6}$ Uzasadnienie tej tezy odwoływało się zarówno do argumentów natury historycznej, jak i do wykładni systemowej. Przywołana autorka trafnie wskazywała, że treść art. 5a pozornie mogłaby sugerować, że wynikające $\mathrm{z}$ tego przepisu ograniczenia dotyczą wyłącznie „praw i obowiązków wynikających z (...) ustawy” nie zaś „warunków wykonywania mandatu”, jak, verba legis, określane są przywileje socjalno-bytowe parlamentarzystów (por. tytuł rozdziału 5 ustawy) ${ }^{7}$. Bez wątpienia natura prawna merytorycznych praw związanych z mandatem poselskim (senatorskim) oraz uprawnień finansowo-socjalnych nie jest tożsama. Pierwsze służą realizacji politycznej funkcji przedstawiciela narodu, drugie mają na celu stworzenie gwarancji służących skutecznemu wypełnianiu tego obowiązku. Stanowisko różnicujące - w kontekście art. 5a - kategorię praw mandatowych od uprawnień socjalno-bytowych stałoby jednak sprzeczności z ustaleniami wynikającymi z wykładni historycznej.

Analiza procesu legislacyjnego ustawy jednoznacznie wskazuje, że celem wnioskodawcy noweli ze stycznia 2005 r. było wyłączenie możliwości korzystania z „uprawnień wynikających z ustawy”, która to kategoria - jak poświadcza uzasadnienie projektu - obejmować miała wszelkie uprawnienia o charakterze finansowo-socjalnym. Nie bez znaczenia - w tym kontekście - jest również fakt, że poprawka Senatu zmierzająca do wyłączenia z zakresu „zawieszonych” praw i obowiązków - prawa do uposażenia i diety parlamentarnej ${ }^{8}$ została przez Sejm odrzucona. W konsekwencji należy przyjąć, że intencją ustawodawcy było ustanowienie rozwiązania, które prowadziłoby do wyłączenia możliwości pobierania uposażenia i diety przez parlamentarzystę w okresie pozbawienia wolności9.

Należy zaznaczyć, że w pracach analitycznych BAS (BSiE) towarzyszących noweli ustawy ze stycznia 2005 r. wskazywano możliwości odmiennej regulacji omawianego zagadnienia: W. Odrowąż-Sypniewski, P. Radziewicz, Propozycje zmian, op. cit.; J. Mordwiłko, Roboczy projekt uzasadnienia dla zmiany ustawy o wykonywaniu mandatu posła i senatora, dotyczącej posła (senatora) pozbawionego wolności, z 20 grudnia 2004 r., 2841/04, niepubl.

6 I. Galińska-Rączy, Prawo posła tymczasowo aresztowanego do odprawy parlamentarnej [w:] Status posła, cz. II, Wybór ekspertyz prawnych do rozdziału 5 ustawy z 9 maja 1996 r. o wykonywaniu mandatu posła i senatora, red. I. Galińska-Rączy, Warszawa 2007, s. 422.

7 Ibidem.

8 Zob. uchwała Senatu z 3 lutego 2005 r.; druk senacki nr 3704/IV kad.

9 Ibidem. 
Nawet jeśli uznać, że argument natury historycznej stanowi zbyt wątłą podstawę, by stwierdzić, że treść art. 5a ogranicza prawa socjalno-bytowe posła pozbawionego wolności, to trudno zarazem zignorować znaczenie art. 23 ust. 10a u.w.m.p.s. dla wykładni systemowej ${ }^{10}$. Przepis ten stanowi m.in, że: $w$ przypadku, o którym mowa $w$ art. 5a, prawa $i$ obowiązki posła i senatora wynikajace z funkcjonowania i znoszenia biura przechodza odpowiednio na Marszałka Sejmu lub Marszałka Senatu. Jego celem jest określenie konsekwencji prawnych zasady wyłączającej wykonywanie wynikających z ustawy praw i obowiązków dla kompleksu spraw związanych z prowadzeniem biura poselskiego. Trzeba podkreślić, że znaczenie normatywne art. 23 ust. 10a nie polega na wyłączeniu możliwości prowadzenia przez posła pozbawionego wolności biura poselskiego, lecz jedynie na określeniu następcy prawnego w sferze praw i obowiązków związanych z funkcjonowaniem biura. Źródłem zasady wyłączającej możliwość prowadzenia biura poselskiego jest - jak wynika z art. 23 ust. 10a u.w.m.p.s. - klauzula wyłączająca w sposób generalny możliwość wykonywania praw i obowiązków poselskich w okresie pozbawienia wolności. Treść art. 23 ust. 10a u.w.m.p.s. dotycząca uprawnień o charakterze organizacyjnym - wskazuje, że ustawodawca uznaje, że formuła zawarta w art. 5a ustawy dotyczy wszelkich praw i obowiązków wynikających z ustawy, czyli zarówno praw merytorycznych związanych $\mathrm{z}$ mandatem poselskim (senatorskim), jak i uprawnień organizacyjnych oraz finansowo-socjalnych.

W konsekwencji należy uznać, że wykładnia art. 5a u.w.m.p.s. - na tle jej innych postanowień - potwierdza tezę, że zawarte w tym przepisie wyłączenie możliwości wykonywania praw i obowiązków wynikających z ustawy dotyczy również prawa do pobierania diety i uposażenia.

3. W myśl art. $261 \S 3$ Kodeksu postępowania karnego (dalej: k.p.k.) sąd jest zobowiązany niezwłocznie powiadomić pracodawcę o zastosowaniu tymczasowego aresztowania. Przepis ten należy uznać za źródło ciążącego na sądzie obowiązku powiadomienia Marszałka Sejmu o zastosowaniu wobec posła izolacyjnego środka zapobiegawczego (tymczasowego aresztowania). Okres tymczasowego aresztowania liczy się od dnia zatrzymania (art. 265 k.p.k.). Przekazana Marszałkowi Sejmu przez sąd informacja o tymczasowym aresztowaniu aktualizuje ograniczenia wynikające $\mathrm{z}$ art. 5a u.w.m.p.s. Poseł pozbawiony wolności na skutek tymczasowego aresztowania i zatrzymania nie może wykonywać praw i obowiązków wynikających z ustawy, w tym również nie przysługują mu uprawnienia socjalno-bytowe. W szczególności w okresie pozbawienia wolności brak jest podstaw prawnych do wypłaty uposażenia i diety poselskiej czy też wypłaty odprawy parlamentarnej na podstawie art. 38 ust. 1 u.w.m.p.s. ${ }^{11}$.

\footnotetext{
10 Ibidem.

11 Ibidem.
} 


\section{Podsumowanie}

Podsumowaniem opinii jest pogląd, że zgodnie z art. 5a u.w.m.p.s. posłowi w czasie pozbawienia wolności nie przysługuje prawo do uposażenia i diety poselskiej. Przekazana Marszałkowi Sejmu przez sąd informacja o tymczasowym aresztowaniu aktualizuje ograniczenia wynikające $\mathrm{z}$ art. 5a u.w.m.p.s. Okres tymczasowego aresztowania liczy się od dnia zatrzymania (art. 265 k.p.k.). Upływ okresu tymczasowego aresztowania, uchylenie przez sąd postanowienia o zastosowaniu izolacyjnego środka zapobiegawczego względnie jego zmiana na środek łagodniejszy przywraca posłowi wcześniej pozbawionemu wolności możliwość pełnego korzystania z praw i obowiązków, a tym samym umożliwia pobieranie uposażenia i diety poselskiej. Obowiązujące przepisy nie przewidują żadnej podstawy prawnej dla podejmowania przez Prezydium Sejmu uchwały potwierdzającej fakt pozbawienia wolności.

\section{Bibliografia}

Galińska-Rączy I., Prawo posła tymczasowo aresztowanego do odprawy parlamentarnej [w:] Status posła, cz. II, Wybór ekspertyz prawnych do rozdziału 5 ustawy z 9 maja 1996 r. o wykonywaniu mandatu posła i senatora, red. I. Galińska-Rączy, Warszawa 2007.

Grajewski K., Komentarz do art. 5a [w:] Komentarz do ustawy o wykonywaniu mandatu posła i senatora, red. K. Grajewski, Warszawa 2014.

Grajewski K., Warunki wykonywania mandatu parlamentarnego przez posła (senatora) tymczasowo aresztowanego lub skazanego na karę pozbawienia wolności [w:] Status posła, cz. I, Wybór ekspertyz prawnych do art. 1-24 ustawy z 9 maja 1996 r. o wykonywaniu mandatu posła i senatora, red. J. Mordwiłko i in., Warszawa 2007.

Mordwiłko J., Możliwość ustawowego uregulowania ograniczenia sprawowania mandatu przedstawiciela pozbawionego wolności, w świetle Konstytucji RP [w:] Status posła, cz. I, Wybór ekspertyz prawnych do art. 1-24 ustawy z 9 maja 1996 r. o wykonywaniu mandatu posła i senatora, red. J. Mordwiłko i in., Warszawa 2007.

Odrowąż-Sypniewski W., Radziewicz P., Propozycje zmian do ustawy o wykonywaniu mandatu posła i senatora, dotyczące statusu posła pozbawionego wolności [w:] Status posła, cz. I, Wybór ekspertyz prawnych do art. 1-24 ustawy z 9 maja 1996 r. o wykonywaniu mandatu posła i senatora, red. J. Mordwiłko i in., Warszawa 2007.

Repel J., Warunki wykonywania mandatu przez posła (senatora) tymczasowo aresztowanego lub skazanego na karę pozbawienia wolności [w:] Status posła, cz. I, Wybór ekspertyz prawnych do art. 1-24 ustawy z 9 maja 1996 r. o wykonywaniu mandatu posła i senatora, red. J. Mordwiłko i in., Warszawa 2007. 